\title{
Зв'язок
}

УДК 621.391

doi: 10.26906/SUNZ.2018.3.165

Я. С. Обіход, В. П. Лисечко, О. М. Прогонний, Г. М. Качуровський, С. В. Сколота

Український державний університет залізничного транспорту, Харків, Україна

Харківський національний університет Повітряних Сил імені Івана Кожедуба, Харків, Україна

\section{РОЗРОБКА МЕТОДУ ВИБОРУ КАНАЛІВ КОГНІТИВНОГО РАДІО \\ ПРИ МНОЖИННОМУ ДОСТУПІ ПЕРВИННИХ ТА ВТОРИННИХ КОРИСТУВАЧІВ 3 ВИКОРИСТАННЯМ ТЕХНОЛОГЇ̈ «ENERGY HARVESTING» ПІД КЕРУВАННЯМ НЕЙРОННОÏ МЕРЕЖІ}

\begin{abstract}
Когнітивне радіо (КР) є однією з основних частин телекомунікаційних систем зв 'язку (ТСС-IОЕ) в зв `язку 3 тим, що були покликані вирішити питання дефіциту спектру та впровадження інтелектуальних функцій. Вибір каналу 3 множинним доступом первинних користувачів (ПК) та вторинних користувачів (ВК) $є$ однією 3 найголовніших проблем стандарту. Через конкуренцію каналів відбувається взаємний вплив пакетів первинних та вторинних користувачів. 3 метою зменшення конкуренції каналів серед вторинних користувачів, було розроблено метод вибору каналів когнітивного радіо при множинному доступі первинних та вторинних користувачів з використанням технології «Energy harvesting» під керуванням нейронної мережі. На основі розробленого методу було реалізовано гібридну модель передачі даних під керуванням нейронної мережі для кожного вторинного користувача. Для цієї моделі характерні властивості, при яких вторинний користувач може випадковим не регламентованим чином працювати в режимах суміщення з зайнятими каналами з використанням технології «Energy harvesting» (EH) та перекриття. Крім того, для реалізації розробленого методу було визначено критерій вибору каналу на основі конкуренції серед множинних запитів вторинних користувачів для передачі даних або технології “ЕН". На основі цього критерію створюється конкуруючий набір послідовностей. Моделювання показує, що запропонований метод спільного використання каналів та критерій вибору каналів перевершують інші методи 3 точки зору помилкової зайнятості (помилки), середньої пропускної здатності, середнього часу очікування та ефективності збору енергії вторинного користувача.
\end{abstract}

Ключов і слова: вторинний користувач, збереження енергії, когнітивне радіо, колізія, нейронна мережа первинний користувач, передача даних, радіо хвилі, радіочастотний спектр.

Постановка проблеми. Останнім часом відбувається безперервна розробка безпроводових пристроїв та послуг, які інтегруються здебільшого в середовище Інтернет (IoE) [1-3]. В мережі Інтернет, де всі елементи пов'язані однією мережею, попит на пропускну здатність при обмеженому спектрі значно зростає. Брак ресурсів радіочастотного спектру став серйозною проблемою 21 століття. Ця проблема пов'язана здебільшого 3 традиційним підходом до розподілу спектру, при якому певна частина спектру може використовуватися тільки ліцензованими системами безпроводового зв'язку.

Дефіцит частотного спектру та наявність «спектральних дір» ліцензованого спектру сприяють появі технологій, таких як технологія когнітивного радіо, яка в даний момент активно розробляється, а Федеральна комісія зі зв`язку (FCC) США схвалила неліцензоване використання ліцензованого спектру, використовуючи когнітивного радіо $[4,5]$. Когнітивне радіо розробляється як ефективний підхід до усунення дефіциту спектру [6-8]. Тому впровадження когнітивного радіо в середовище ІоЕ може забезпечити доступ до фіксованих частот між декількома користувачами.

В конітивному радіо було запропоновано механізм динамічного спектрального доступу (DSA). Існують дві основні моделі передачі даних для ВК, що ефективно використовують «спектральні діри»: режим перекриття (РП) [9] та суміщення (РС) [10]. В режимі перекриття ВК може не регламентованим чином використовувати ліцензовані частоти тільки в тому випадку, якщо первинний користувач не активний. Тобто, вторинний користувач не має доступу до спектру одночасно 3 первинним користувачем, щоб запобігти будь-яким помилкам при передачі первинного користувача. В режимі суміщення, якщо первинний користувач отримує доступ до своєї частоти, вторинний користувач може співіснувати 3 передачею даних первинному користувачу, доки завади, викликані вторинними користувачами, не погіршать якість зв'язку первинного користувача до певного рівня. Коли первинний користувач переходить в неактивний стан, потужність передачі вторинного користувача буде обмежена порогом, вказаним в цьому режимі. Тому частоти незайнятого спектру не використовуються в повній мірі, і вторинний користувач в режимі суміщення не забезпечує максимальну продуктивність. 3 іншого боку, коли в певній області частот спостерігається висока активність використання спектру, протягом якого вторинний користувач повинен чекати на вільний канал, це значно знижує продуктивність режиму перекриття. Тому існує необхідність розробки гібридної моделі передачі даних на основі нейронної мережі, в якій переваги режиму перекриття та режиму суміщення будуть поєднані так, щоб продуктивність вторинного користувача була б максимальною при великій мінливості стану первинного користувача. 
Аналіз літератури. В джерелах [12-14] було запропоновано гібридну модель передачі даних. Згідно джерела [12], вторинний користувач може обмінюватися керуючою інформацією як в режимі перекриття, та передавати дані, так само, як і в режимі суміщення. Таке рішення, про доступ та передачу, носить лише теоретичний характер. В джерелах $[13,14]$ вторинний користувач постійно аналізує спектр на наявність активності первинного користувача та передає дані так само, як і в режимі перекриття, коли факт роботи первинного користувача не виявлено. Якщо первинний користувач починає передавати дані, то, при цьому, вторинний користувач звільняє канал як і при режимі суміщення. Але в розглянутих роботах не враховувалися помилки при виявленні та повторна передача первинного користувача. В наведених роботах було показано, що вторинний користувач може покращити показники доступу до спектру в гібридній моделі передачі порівняно 3 двома стандартними режимами. Але питання про двох або більше вторинних користувачів, які конкурують за один канал практично не вивчавлося. Більш того, імовірність виникнення помилок між вторинним та первинним користувачами збільшується в режимі множинних вторинних користувачів [15]. Таким чином, через важливість запобігання помилок співіснування, в мережі когнітивного радіо з декількома вторинними користувачами та декількома каналами, існує необхідність розробки критерію вибору канала в гібридній моделі передачі на основі нейронної мережі для вирішення проблем помилок співіснування.

Енергоспоживання $є$ важливою проблемою безпроводового зв'язку. В мережах з множинними вторинними користувачами, які використовують безліч первинних каналів в гібридній моделі передачі, вторинний користувач буде витрачати більше енергії, ніж в стандартних методах, через те, що він буде постійно аналізувати, виявляти та переключатися між великою кількістю каналів. Тому енергоефективність $\epsilon$ важливим критерієм в мережах когнітивного радіо поряд з ефективним використанням спектру $[16,17]$. В сучасних джерелах описано нові методи ефективного енергозбереження $[18,19]$. Такі технології дозволяють пристроям акумулювати енергію з природних джерел: сонячних, повітряних, акустичних та радіочастотних хвиль (РХ). Основна концепція полягає в тому, що відбувається перетворення навколишніх електромагнітних хвиль в електричну енергію. Такий підхід $є$ більш відповідним та стабільним для пристроїв з низьким енергоспоживанням, аналізуючих систем, мереж когнітивного радіо, ніж підхід 3 іншими джерелами. Припускається, що вториннний користувач оснащений здатністю збору енергії радіохвиль і повинен не тільки обирати незайнятий канал для передачі даних, але і зайнятий канал для збору радіочастотної енергії. Відповідно, такий гібридний метод вибору каналу передачі даних актуальний для покращення ефективності використання спектру, так і для ефективності використання енергії в мережах когнітивного радіо.

Виходячи $з$ вищеописаних переваг, в статті розроблено метод на основі конкуренції каналів між вторинними користувачами для досягнення мінімальної кількості помилок в каналах 3 первинними користувачами в мережі когнітивного радіо 3 великою кількістю первинних та вторинних користувачів.

На сьогоднішній день не існує ефективного вирішення конкуренції каналів між декількома первинними та вторинними користувачами[10, 20, 21]. Грунтуючись на методі виявлення і концепції конкуренції каналів, для вирішення поставлених задач буде отримано можливість покращення точності аналізу спектру і пропускної здатності вторинних користувачів. Крім того, спираючись на розроблений метод, вторинні користувачі зможуть акумулювати радіочастотну енергію з зайнятих каналів, використовуючи технологію «Energy Harvesting».

Мета статті. Метою статті $є$ розробка методу суміщеного використання спектру для зменшення імовірності помилок при виявленні вільних каналів та для зменшення кількості помилок при передачі вторинними користувачами, а також реалізація процедури вибору каналу для великої кількості вторинних користувачів на основі конкуруючого набору.

Основний матеріал. На рисунку 1 показано мережу з великою кількістю первинних та вторинних користувачів, де кожному первинному користувачеві виділено ліцензований канал («ПК-канал»). Як і в [9-11], трафік кожного каналу моделюється як марківський процес безперервний у часі. Такий процес має два стани - вільного і зайнятого спектру, що для первинного користувача відповідає включеному та виключеному стану. Кожний передавач вторинного користувача та відповідний йому приймач знаходиться в межах діапазону передачі один одного. Отже, існування зв'язку між двома вторинними користувачами залежить не тільки від відстані між ними, але і від передачі первинного користувача, що змінюється у часі.

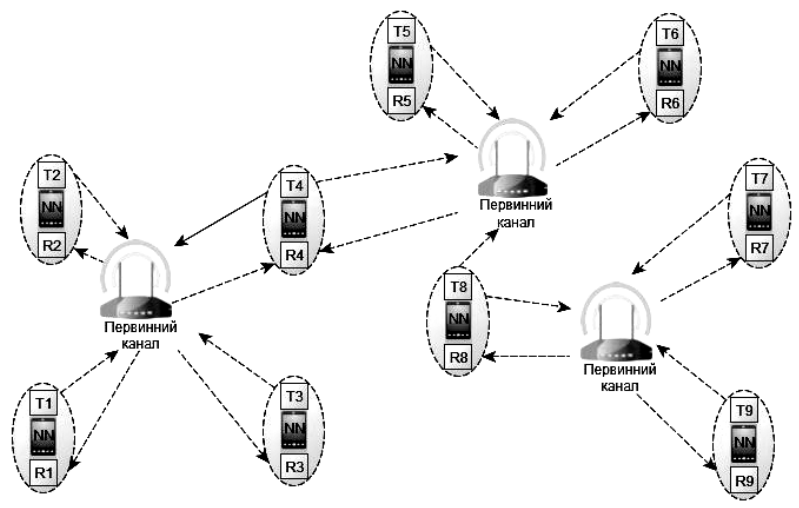

Рис. 1. Архітектура мережі когнітивного радіо з великою кількістю первинних та вторинних користувачів

3 рис. 1 видно, що декілька вторинних користувачів можуть мати доступ до одного каналу, а один вторинний користувач може мати більше одного каналу для вибору.

Первинний користувач знаходиться в діапазоні передачі деяких вторинних користувачів. Відповідно, потужність каналу повинна бути збільшена:

1) від передавача первинного користувача до приймача (Gpp); 
2) від передавача вторинного користувача до приймача(Gss);

3) від передавача первинного користувача до приймача вторинного користувача (Gps);

4) від передавача вторинного користувача до приймача первинного користувача (Gsp).

Модель такої системи має вигляд [25]:

$$
G_{i j}=k \cdot d_{i j} \cdot \alpha,
$$

де $G_{i j}$ - потужність каналу i-ï передачі та ј-го прийому; $\mathrm{k}$ - коефіцієнт загасання, який показує зміну потужності; $d_{i j}-$ відстань між і-го передавача та ј-го приймача; $\alpha$ - втрати при i-й передачі та j-му прийомі.

Рівень потужності та інформація про стан каналу (CSI) будуть відомі вторинному користувачу, в результаті чого він може отримати доступ до каналу після його виявлення.

Енергія від радіочастотного сигналу транслюється у всіх напрямках [18]. Але у зв язку з невизначеним місцем розташування, загасаннями, завадами та умовами розповсюдження рівень енергії радіохвиль не може гарантувати QoS в безпроводових радіосистемах. Щоб покращити енергоефективність, енергія від радіохвиль перетворюється в постійну напругу, а потім зберігається в джерелі безперебійного живлення. Даною технологією визначено ефективну зону збору енергії. Така технологія передбачає, що кожен вторинний користувач може перетворити енергію тільки 3 радіохвиль від каналів первинного користувача. Кожен передавач вторинного користувача повинен бути оснащений приладом перетворення енергії та зберігати зібрану енергію в джерелі безперебійного живлення, який визначено максимальною ємністю $\mathrm{E}_{\max }$. При цьому джерело безперебійного живлення моделюється ідеальною лінійною моделлю, де зміни в накопиченій енергії 3 каналів первинних користувачів для виявлення або передачі даних, що збільшує енергоефективність.

Виявлення спектральних «дір» $є$ основою механізму DSA. Крім того, помилково знайдені канали впливають на продуктивність передачі вторинних користувачів та призводять до виникнення помилок в роботі первинних користувачів.

Спектральний аналіз повинен виконуватися перед передачею даних для виявлення доступності каналу. Більшість методів застосовуються вторинними користувачами для виявлення активності первинних користувачів [9]. Метод детектування енергетичної складової простий в реалізації і показує реальну картину зайняття каналів. Тому такий метод $€$ більш точним, навіть якщо вторинний користувач практично не має інформації про первинного користувача і взятий за основу в розробці методу як алгоритм зондування спектру. Тобто, основною метою вимірювання спектра є визначення зайнятості каналу в ліцензованій смузі частот. У відповідності 3 двома гіпотезами, описаними нижче, сигнал може бути виражений як [13]:

$$
\begin{aligned}
& H_{0}: x(t)=n(t), \\
& H_{1}: x(t)=s(t)+n(t) .
\end{aligned}
$$

де $H_{0}, H_{1}$ - дві гіпотези про зайнятість або вільність каналу; $n(t)$ - адитивний білий гаусів шум (AWGN); $s(t)$ - сигнал первинного користувача в обраному каналі.

В [22] передбачається, що імовірність виявлення можна позначити через $\mathrm{P}_{\mathrm{d}} 3$ фіксованим SNR $\gamma$ в каналі з AWGN i iï можна представити як [14]:

$$
P_{d}(\gamma, \tau, \lambda)=\alpha\left(\left(\frac{\lambda}{\sigma^{2}}-\lambda-1\right) \sqrt{\frac{\tau f_{s}}{2 \gamma+1}}\right),
$$

де $\tau$ - тривалість виявлення; $\lambda$ - поріг виявлення; $f_{s}$ частота дискретизації; $\sigma$ - дисперсія AWGN; $\alpha$ імовірність нормального розподілу.

При помилковому виявленні можливе виникнення двох типів помилок: хибна помилка і, власне, помилкове виявлення. Хибна помилка виникає, коли канал вільний, а вторинний користувач вважає, що канал зайнятий. При помилковому виявленні вторинний користувач ідентифікує канал як вільний, який фактично зайнятий. Звідси випливає, що хибна помилка вказує на невикористану можливість доступу до спектру, в той час як помилкове виявлення вносить потенційні завади в каналі 3 первинним користувачем. Імовірності виявлення хибної помилки $\mathrm{f}_{\mathrm{s}}$ та помилкового виявлення $\mathrm{f}_{\mathrm{m}}$ можуть бути представлені, відповідно, як [26]:

$$
\begin{gathered}
P_{f}(\tau, \lambda)=\alpha\left(\left(\lambda / \sigma^{2}-1\right) \sqrt{\tau f_{s}}\right), \\
P_{m}(\gamma, \tau, \lambda)=1-\alpha\left(\left(\lambda / \sigma^{2}-(1+\gamma)\right) /(1+\gamma) \sqrt{2 /\left(\tau P_{s}\right)}\right) .
\end{gathered}
$$

Через ефекти багатопроменевого завмирання, всередині високих будівель з високими втратами і локальними перешкодами та завадами, ймовірності хибної помилки і помилкового виявлення збільшуються при не суміщених методах виявлення, що призводить до помилок при прийомі-передачі між первинними та вторинними користувачами в мережах когнітивного радіо. У дослідженнях $[11,13,19]$ було частково вирішено цю проблему. У розробці методу вибору каналів когнітивного радіо при множинному доступі первинних і вторинних користувачів під керуванням нейронної мережі дані будуть збиратися, аналізуватися і об'єднуватися для більш точного моделювання.

На рис. 2 зображено структуру з часовим інтервалом (TS). Такий TS складається 3 двох фаз, однією $з$ яких є фази виявлення каналу (CS) і передачі даних (DT) або фази «збору» енергії. На першому етапі вторинні користувачі виявляють канали з активністю первинного користувача і обмінюються інформацією про зайняті або виявлені вільні канали даних вторинного користувача 3 іншими вторинними користувачами. Потім цю інформацію буде порівняно 3 відповідними результатами вимірювань вторинних користувачів. Остаточне рішення про стан виявленого каналу буде прийматися на підставі двох або більше підтверджених станів. Також канал може бути визначено, коли він виявляється тільки одним вторинним користувачем. На другому етапі 
вторинний користувач здійснює «збір» енергії або DT на підставі певного стану каналу. Виходячи 3 [23] тривалість виявлення повинна бути настільки малою в порівнянні 3 часом передачі інформації первинного користувача, що можна припустити, що стан передачі інформації первинного користувача $€$ незмінним під час фаз виявлення.

\begin{tabular}{|c|c|c|c|}
\hline \multirow{2}{*}{ Канал } & \multirow{2}{*}{ Стан } & Рішення & Передача даних \\
& & "Збір" енергії \\
\hline
\end{tabular}

Рис.2. Структура пакета з часовим інтервалом

На рис. 3 наведено гібридну модель передачі даних. Дані, що надходять, буферизуються в черзі даних передавача вторинного користувача $Q_{D i}$, де $I=1 \ldots N$, при максимальному об ємі черги даних $Q_{\max }$. Енергетична складова радіохвиль зберігається в джерелі безперебійного живлення, $Q_{E i}$, де $i=1 \ldots N$, максимальна ємність якого позначається як $E_{\max }$.

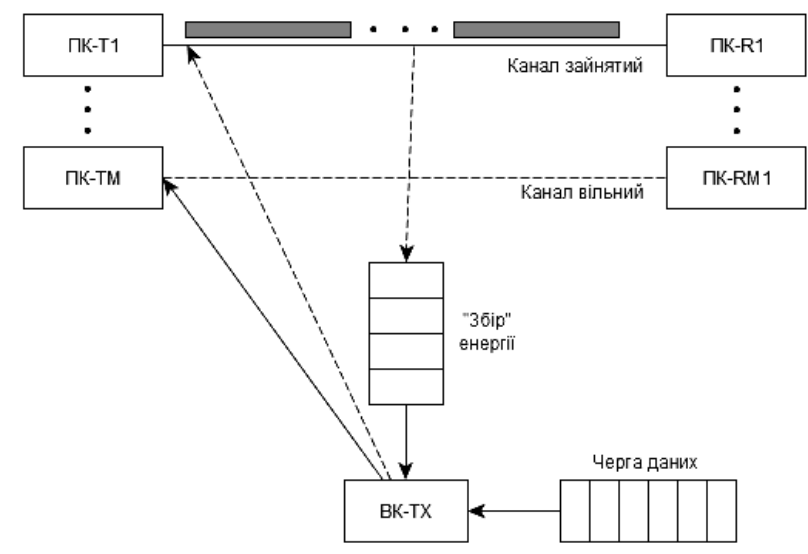

Рис. 3. Гібридна модель передачі даних

При ініціалізації каналу, коли дані надходять на передавач вторинного користувача, черга даних i енергетична ємність можуть бути представлені при $Q_{D i} \neq 0$, як $Q_{D i}=E_{\text {max }}$. Вторинний користувач може виконувати передачу даних при виявленні незайнятих каналів. Нехай E(s) буде визначальним результатом вторинного користувача, а $\lambda_{0}$ та $\lambda_{\mathrm{u}}-$ енергетичний поріг моделі перекриття та суміщення, відповідно. Якщо енергія сигналу радіохвиль буде нижчою порогу суміщення, то $\mathrm{E}(\mathrm{s})<\lambda_{0}$. Відповідно, вторинний користувач буде передавати дані з більшою швидкістю в режимі перекриття. Якщо енергія сигналу радіохвиль буде вищою порогу перекриття, але нижчою порогу суміщення, то $\lambda_{0}<\mathrm{E}(\mathrm{s})<\lambda_{\mathrm{u}}$. Це означає, що первинний користувач не повністю займає виділений канал, і вторинний користувач може отримати до нього доступ одночасно 3 первинним користувачем. Вторинний користувач, зменшує потужність передавача так, щоб не заважати передачі первинного користувача, що відповідає моделі суміщення.

При використанні гібридної моделі передачі передбачається, що кожен передавач вторинного користувача володіє достовірною CSI. Для різних каналів величина і коефіцієнт використання різні. Грунтуючись на результатах вимірювання каналів, кожен вторинний користувач самостійно обчислює статистичний поріг енергії в режимі суміщення та перекриття, і оновлюється до одного $з$ двох станів виявлення помилок.

При надходженні даних на приймач вторинного користувача, він здійснює порівняння результатів поточного стану каналу з інформацією CSI, визначає потужність первинного користувача на підставі відстані і посилення антени, в тому випадку, якщо первинний користувач повністю не займає цей канал [24]. Для режиму перекриття немає обмеження для потужності передачі вторинного користувача. Для зміни поточного стану каналу в режим сполучення, через виникнення завад, викликаних впливом роботи вторинного користувача на канал первинного користувача, необхідно зменшити потужність передачі, змінити тип модуляції і визначити тип кодування, для забезпечення відповідного SNR.

При порожньому буфері даних вторинний користувач використовує енергозберігаючий режим, при якому $Q_{D i}=0, Q_{D i} \neq E_{\max }$, тобто вторинний користувач може «збирати» радіочастотну енергію зі спектра. Відповідно, якщо енергія такого каналу більше порогу моделі поєднання, то вторинний користувач може здійснювати «збір» енергії з неї.

У такій гібридній моделі передачі даних вторинний користувач може визначити, чи здійснювати йому передачу даних або «збір» енергії в залежності від буфера даних або стану джерела безперебійного живлення. Грунтуючись на результатах вимірювання спектра і порогових значеннях режиму суміщення або перекриття, кожен вторинний користувач може як отримувати доступ до каналу з ПК, так і накопичувати енергію з каналів, зайнятих первинним користувачем. Нейронна мережа, використовуючи накопичену інформацію про стани каналу, топології виявлених каналів, рівня випромінювання, дальності, приймає рішення про перехід на новий канал для передачі даних на зайнятих частотах для «збору» енергії або передачі даних в наступних фазах CS. Процес вибору режиму передачі для кожного вторинного користувача представлено на рис. 4.

На підставі розробленого методу гібридної моделі передачі даних кожен вторинний користувач може або передавати дані у вільному каналі, або здійснювати «збір» енергії з зайнятого каналу. Для мережі когнітивного радіо з великою кількістю первинних та вторинних користувачів однією 3 ключових проблем, пов'язаних $з$ доступом до багатоканальних систем, є проблема конкуренції між вторинними користувачами. В статті було розроблено критерій передбачуваного вибору каналу.

Якщо виявлений незайнятий канал, передавач вторинного користувача відправляє пакет RTS по каналу на приймач вторинного користувача. Потім вторинний користувач, що приймає, відповідає пакетом CTS в тому ж каналі. У каналі можуть виникати колізії RTS i CTS пакетів, якщо один і той же канал використовує більше однієї пари вторинних користувачів. Відповідно, пара вторинних користувачів отримує доступ до каналу не відразу, а після того як один з них отримав CTS пакет. 


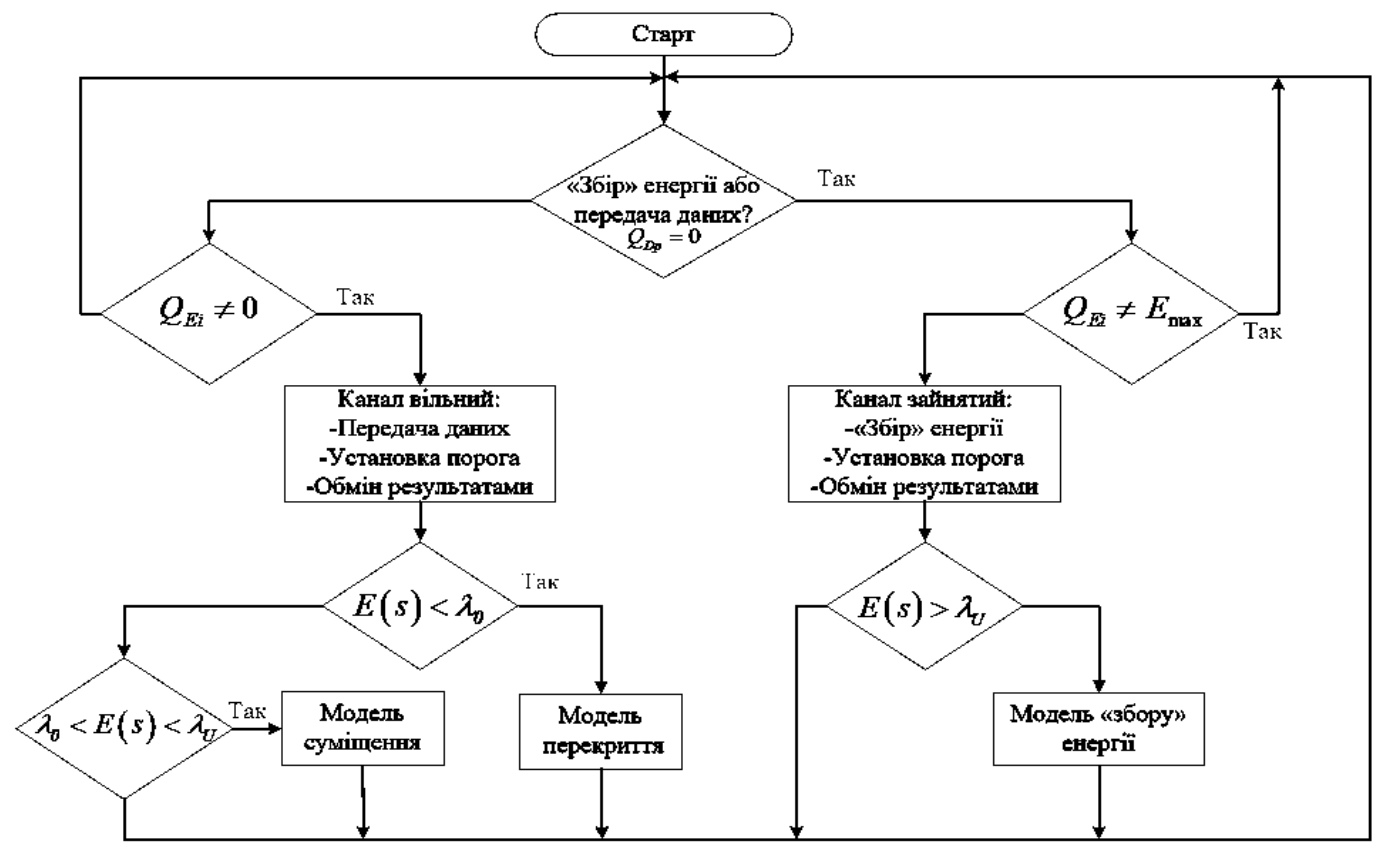

Рис. 4. Процес выбору режиму передачі вторинного користувача

Ti вторинні користувачі, які отримують CTS пакет утворюють конкуруючий набір $-S_{I i}=1 \ldots M$, який показує, що ці вторинні користувачі конкурують за доступ до каналу первинного користувача. Припустимо, що розмір $S_{I i}$ - це $W$, якому довільно присвоюємо значення від 0 до $W-1$. Вторинний користувач, який має $W=0$, може передавати дані в режимі DT. Якщо вторинний користувач виявляє більше одного каналу, він може конкурувати за кілька незайнятих каналів і отримувати кілька значень 3 конкуруючого набору. Для збільшення пропускної спроможності нейронна мережа може розділити передачу даних на кілька каналів, при умові, якщо вона отримала нульове значення 3 конкуруючого набору. Коли канал може бути доступним лише в режимі суміщення для передачі даних, ті вторинні користувачі, які отримують CTS пакет, утворюють конкуруючий набір, $S_{U i}=1 \ldots M$.

Вторинний користувач буде передавати дані до тих пір, поки стан каналу не зміниться і результат поточного стану не буде дорівнювати $E(s)<\lambda_{0}$ в наступному режимі CS. Коли вторинний користувач «виходить» 3 поточного каналу, всі інші вторинні користувачі автоматично встановлюють значення конкуруючого набора в W-1. Результат стану каналу буде $\lambda_{0}<\mathrm{E}(\mathrm{s})<\lambda_{\text {u }}$ в наступному CS режимі, тобто якщо первинний користувач не повністю займає весь канал для передачі в даний момент часу, вторинний користувач знижує рівень потужності, щоб були дотримані обмеження потужності перешкод первинного користувача, вказані в режимі суміщення. Якщо передача вторинного користувача призводить до виникнення завад в каналах первинного користувача при $\mathrm{E}(\mathrm{s})>\lambda_{\mathrm{u}}$, то передача даних буде припинена в наступній фазі DT, конкуруючий набір буде дорівнювати NULL. Алгоритм вибору каналу для передачі даних показано на рис. 5. Всі користувачі $l_{n}$, де $n \notin[1$, $N]$ включаючи $l_{m}$ займають вільні канали, $m \notin[1, M]$ та $p$ вторинного користувача, $p \notin[1, P]$.

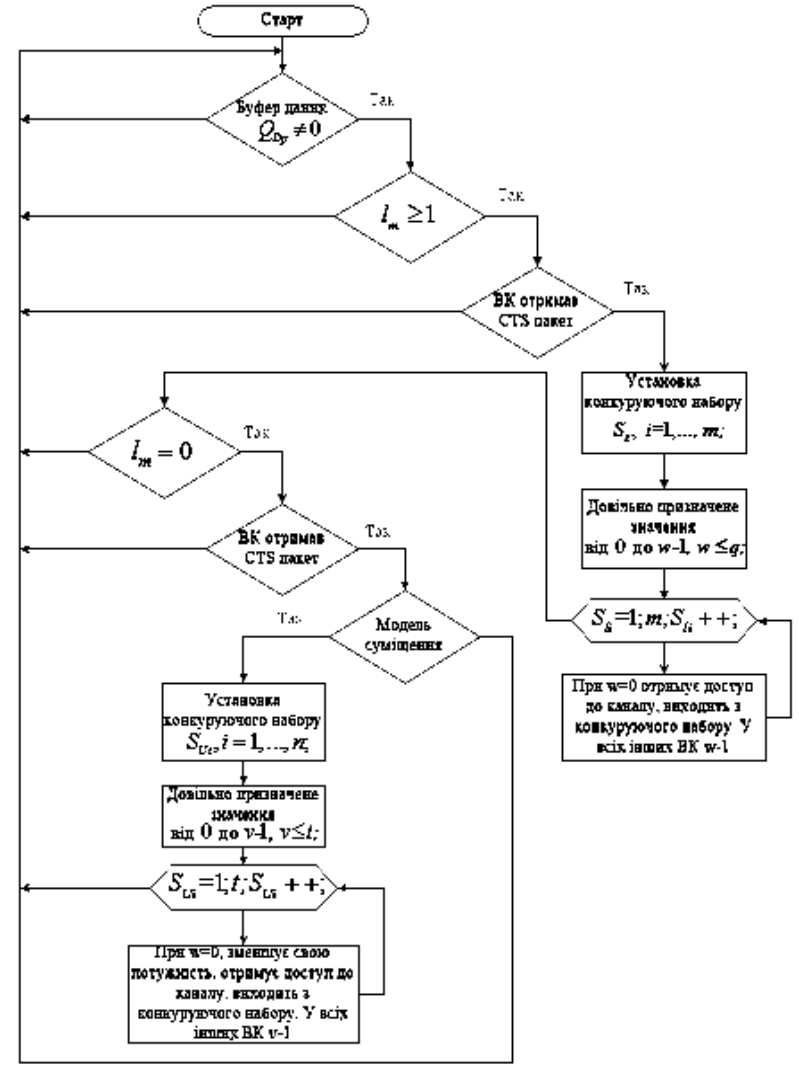

Рис. 5. Алгоритм вибору каналу для передачі даних

На рис. 6 наведено приклад довільного присвоєння конкуруючого набору. Чотири вторинних користувачі виявляють поточну доступність каналу, отримують список вільних і зайнятих каналів. Вторинні користувачі, які конкурують за один і той же канал, утворюють конкуруючий набір, тобто 1й, 2й, Зй вторинний користувач може використовувати канал А. Цим вторинним користувачам присвоюються довільні значення конкуруючого набору. Той вторинний користувач, який отримує нульове зна- 
чення, може отримати доступ до каналів і вийти з закріпленого конкуруючого набору, в той час як значення конкуруючого набору інших вторинних користувачів буде зменшуватися на один. 3 рисунку 6 видно, що вторинний користувач під номером два може використовувати канали А і В. В наступному часовому інтервалі вторинний користувач під номером чотири може отримати доступ до каналу В.

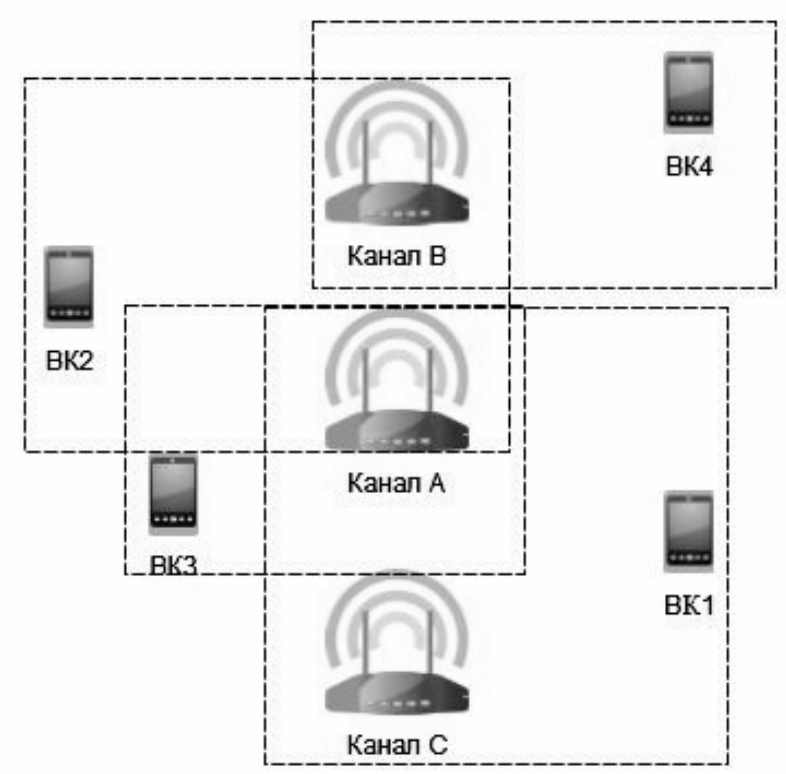

Рис. 6. Приклад довільного присвоєння конкуруючого набору

Вторинні користувачі, які конкурують за один і той же канал, утворюють конкуруючий набір, $S_{E j}=$ $1,2,3, \ldots, M$. Це означає, що ці канали конкурують за доступ до каналу первинного користувача і можуть накопичувати енергію. Створюється ще один конкуруючий набір, і той вторинний користувач, який отримав нульове значення, в наступній фазі ЕН буде накопичувати енергію. Вторинний користувач виходить 3 конкуруючого набору, якщо відбувається початок передачі даних з цим вторинним користувачем, або якщо джерело безперебійного живлення заповнилося. Приклад функціонування алгоритму вибору каналу для накопичення енергії наведено в табл. 1 на рис. 7.

Табличя 1. Випадковий розподіл значень конкуруючого набору

\begin{tabular}{|c|c|c|c|c|c|}
\hline $\begin{array}{c}\text { Кори- } \\
\text { стувач }\end{array}$ & $\begin{array}{c}\text { Вільний } \\
\text { канал }\end{array}$ & $\begin{array}{c}\text { Довільне } \\
\text { значення } \\
\mathbf{1}\end{array}$ & $\begin{array}{c}\text { Канале- } \\
\text { пере- } \\
\text { дачі 1 }\end{array}$ & $\begin{array}{c}\text { Довільне } \\
\text { значення } \\
\mathbf{1}\end{array}$ & $\begin{array}{c}\text { Канал } \\
\text { пере- } \\
\text { дачі 1 }\end{array}$ \\
\hline 1 & А, С & 1 & С & 0 & С \\
\hline 2 & А, Б & 0 & А & 0 & А \\
\hline 3 & А & 2 & - & 1 & - \\
\hline 4 & В & 1 & - & 0 & В \\
\hline
\end{tabular}

Для визначення критерію вибору каналу приймач вторинного користувача відправляє пакет передавачу вторинного користувача, за умови, якщо поточну передачу завершено і дані успішно прийнято. Прапор перемикання каналів (CSW) встановлю- ється при необхідності вторинного користувача переключитися на інший канал, після чого вторинний користувач дотримується процедур розриву зв'язку - «handoff» і виконує перемикання каналу.

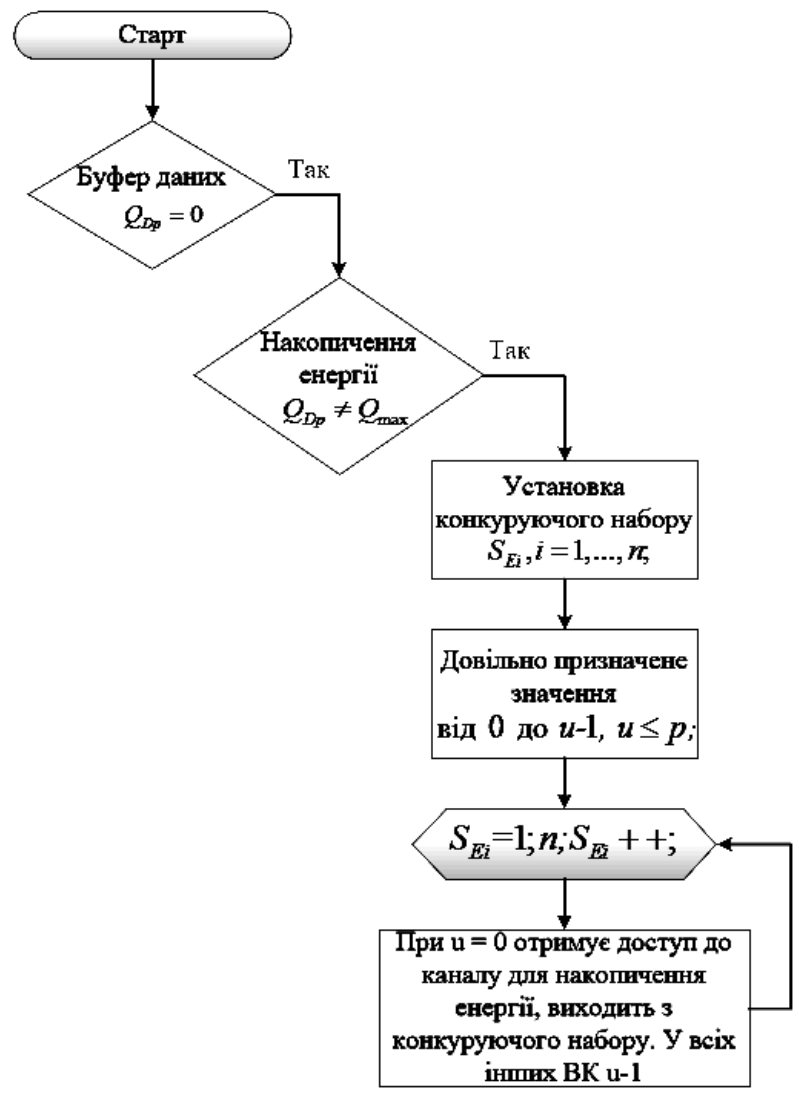

Рис. 7. Алгоритм вибору канала для накопичення енергії

Протокол CSMA/CA використовує процедури встановлення зв'язку-«handshake», щоб мінімізувати зіткнення пакетів серед користувачів і алгоритм експоненціальної відмови. Кожен користувач робить випадкову затримку $\mathrm{t}$, коли відбувається зіткнення пакетів, де $\mathrm{t}$ приймає значення від 0 до Т в нижній частині експоненціального розподілу. Така політика забезпечує використання вільних каналів шляхом створення конкуруючих наборів і випадкового присвоєння значень. Для зменшення середнього часу очікування вторинні користувачі, які мають доступ до каналів, виходять 3 конкуруючих наборів, в той час як значення конкуруючого набору вторинного користувача зменшується на один.

Алгоритм визначення критерію вибору каналу вторинного користувача забезпечує передачу даних в режимі перекриття або суміщення. Швидкість обслуговування кожного вторинного користувача в гібридній моделі описується як $R_{h}=R_{o}+R_{u}$, де $R_{h}=$ $R_{o}+R_{u}$ і може бути виражена через $R_{o}^{0}, R_{o}^{1}, R_{O}^{0^{\prime}}, R_{O}^{1^{\prime}}$ в моделі перекриття [27]:

$$
\begin{gathered}
R_{o}^{0}=B \log _{2}\left(1+g_{s} P_{s}^{o}\right), \quad R_{o}^{1}=0, \\
R_{o}^{0^{\prime}}=B \log _{2}\left(1+\frac{g_{s} P_{s}^{o}}{g_{p} P_{p}+1}\right), \quad R_{o}^{1^{\prime}}=0,
\end{gathered}
$$


де $R_{o}^{0}$ - показник того, що первинний користувач не займає канал; $R_{O}^{1}-$ показник того, що первинний користувач займає канал; $R_{o}^{0^{\prime}}$ та $R_{o}^{l^{\prime}}-$ показники норми обслуговування кожного вторинного користувача при хибній помилці або помилковому виявленні. В моделі суміщення $R_{u}$ може бути позначена як $R_{u}^{0}(7)$ та $R_{u}^{1}(8)$ відповідно:

$$
\begin{gathered}
R_{u}^{0}=B \log _{2}\left(g_{s} P_{s}^{u}\right) \\
R_{u}^{0^{\prime}}=B \log _{2}\left(1+g_{s} P_{s}^{u} /\left(g_{p} P_{P}+1\right)\right)
\end{gathered}
$$

Пропускна здатність вторинного користувача описана в [28]:

$$
T=1-p_{\text {out }},
$$

де $p_{\text {out }}$ - імовірність відмови.

Пропускна здатність критерія вибору каналів $T_{h}$ складається з $T_{o}$ i $T_{u}$. $T_{o}$ описується виразом:

$$
T_{o}=p_{i}\left(1-p_{f}\right)\left(1-p_{\text {out }}^{o}\right)+\left(1-p_{i}\right) p_{f}\left(1-p_{\text {out }}^{o^{\prime}}\right),
$$

де $p_{i}$ - імовірність «простою» каналу; $p_{\text {out }}^{o}$ та $p_{\text {out }}^{o^{\prime}}$ хибна помилка та помилкове виявлення, які, відповідно, можуть бути виражені як (11) та (12):

$$
\begin{aligned}
& p_{\text {out }}^{o}=\operatorname{Pr}\left[R_{o}^{0}<R_{S}\right], \\
& p_{\text {out }}^{o^{\prime}}=\operatorname{Pr}\left[R_{o}^{0^{\prime}}<R_{S}\right],
\end{aligned}
$$

де $R_{s}$ - прийнятна швидкість обслуговування вторинного користувача. Виходячи 3 вищеописаного ми можемо отримати $T_{u}(13), p_{\text {out }}^{u}$ (14) та $p_{\text {out }}^{u^{\prime}}(15)$ :

$$
\begin{gathered}
T_{u}=p_{i}\left(1-p_{f}\right)\left(1-p_{\text {out }}^{u}\right)+\left(1-p_{i}\right) p_{f}\left(1-p_{\text {out }}^{u^{\prime}}\right), \\
p_{\text {out }}^{u}=\operatorname{Pr}\left[R_{u}^{0}<R_{s}\right], \\
p_{\text {out }}^{u^{\prime}}=\operatorname{Pr}\left[R_{u}^{0^{\prime}}<R_{s}\right] .
\end{gathered}
$$

У формулі (16) показано час, що минув від прийому сигналу RTS до повної передачі даних, між кожним вторинним користувачем. Цей час відображає продуктивність конкуруючого набору. Нейронна мережа дозволяє більш прийнятно визначити вибір конкуруючого набору ніж звичайний критерій випадкового доступу. Середній час очікування вторинного користувача може бути описаний як:

$$
T_{w}=T_{t}-T_{R T S},
$$

де $T_{t}$ та $T_{R T S}$ - час прийому-передачі вторинного користувача.

Ефективність накопичення енергії описується 3 точки зору залишкової енергії та може бути описана:

$$
e_{r}^{t+1}=\min \left[e_{r}^{t}+e_{h}-\left(e^{t}+e_{s}+e_{c}\right), E_{\max }\right],
$$

де $e_{h}$ - «пакети» енергії, які були зібрані вторинним користувачем в зайнятих каналах; $e_{t}$ та $e_{s}$ - енергія, споживана вторинним користувачем для передачі даних та виявлення каналів в спектрі, відповідно; $e_{c}-$ інші втрати енергії; $e_{r}^{t}$ - залишкова енергія в часовому інтервалі t.

Розглянемо чисельні результати реалізації методу вибору каналів когнітивного радіо при множинному доступі первинних і вторинних користувачів $з$ використанням технології «Energy Harvesting» під керуванням нейронної мережі. В таблиці 2 наведено параметри моделювання. Розглянуто мережу 3 20 первинними користувачами, 20 каналами і 25 парами вторинних користувачів. Для моделювання буде взята нейронна мережа на основі радіальної базисної мережі (РБМ), яка буде керувати виявленням каналів, прийомом i передачею інформації, накопиченням енергії. Така нейронна мережа зможе звертатися до одного каналу і зможе мати більше одного каналу для вибору. Всі частоти спектра мають однаковий розмір, а довжина пакету первинного та вторинного користувачів буде фіксована.

Таблиця 2. Параметри моделювання

\begin{tabular}{|c|c|c|c|}
\hline Параметр & Значення & Параметр & Значення \\
\hline$p_{i}$ & 0,8 & $R_{S}$ & $3 \mathrm{bps}$ \\
\hline$\lambda_{0}$ & 0,3 & $P_{P}$ & $15 \mathrm{~dB}$ \\
\hline$\lambda_{u}$ & 0,7 & $t$ & $2 \mathrm{~ms}$ \\
\hline$E_{\max }$ & 15 & $T$ & $250 \mathrm{bit}$ \\
\hline$Q_{\max }$ & 20 & $C T S$ & $250 \mathrm{bit}$ \\
\hline
\end{tabular}

На рис. 8 показано результати оцінки ймовірності хибної помилки при суміщеному і не суміщеному методі аналізу спектра з великою кількістю вторинних користувачів. Очевидно, що ймовірність хибної помилки зменшується зі збільшенням імовірності виявлення. Для непоєднаного методу аналізу спектру кількість вторинних користувачів не впливає на імовірність хибної помилки. При фіксованій імовірності виявлення суміщений метод аналізу спектру може забезпечити більш високу точність виявлення. Як описано вище, два і більше таких же результатів вважаються остаточним рішенням для доступу до каналу. Відповідно, ймовірність хибної помилки значно зменшується, коли вторинних користувачів буде два або три. Імовірності помилкового виявлення при ймовірності виявлення 0,85 зменшується швидше, коли кількість вторинних користувачів три або чотири. Т.ч., метод суміщеного аналізу спектру може підвищити точність виявлення каналу. Але використання при розрахунках вторинних користувачів, кількістю більше чотирьох, значно не вплине на імовірність хибної помилки. На рис. 9 показано середню пропускну здатність вторинного користувача у відомих моделях передачі даних і гібридній моделі з використанням нейронної мережі при різних кількостях зайнятих каналів. Як видно з рисунку, середня пропускна здатність вторинного користувача зменшується в моделі перекриття тільки при збільшенні кількості зайнятих каналів. 


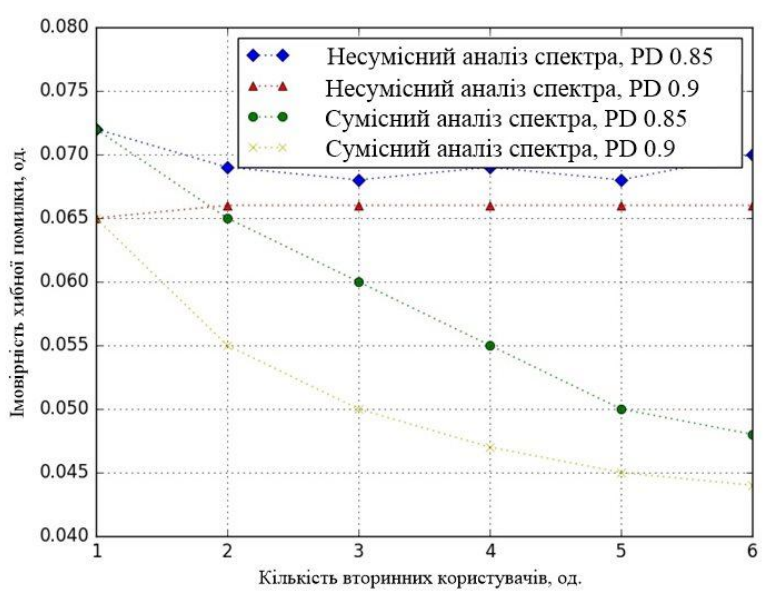

Рис. 8. Імовірність хибної помилки при суміщеному і несуміщеному методах аналізу спектра вторинного користувача

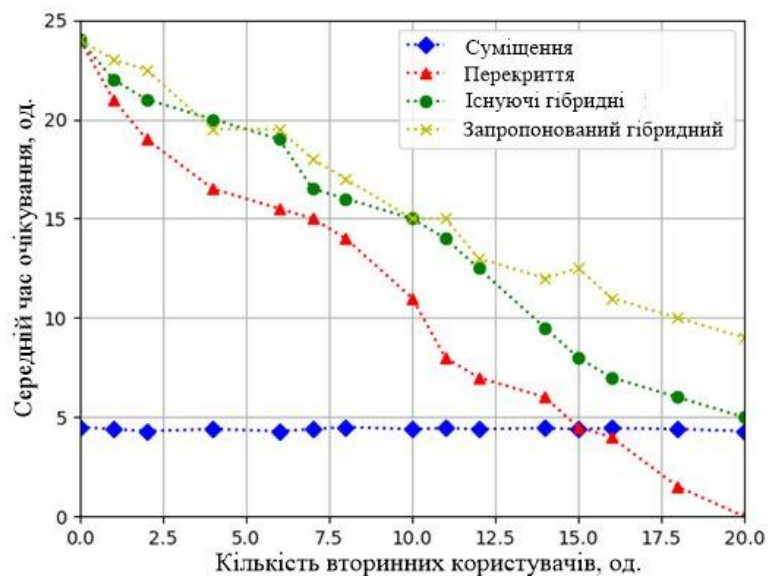

Рис. 9. Вплив моделі передачі на середню пропускну здатність вторинного користувача при різній кількості зайнятих каналів

Це пов'язано з тим, що велика кількість зайнятих каналів обмежує передачу вторинних користувачів лише в моделі перекриття. У моделі поєднання середня пропускна здатність практично не змінюється в зв'язку з тим, що вторинні користувачі можуть співіснувати 3 первинними користувачами. Запропонована гібридна модель 3 використанням нейронної мережі може забезпечити більш високу пропускну здатність у порівнянні 3 існуючими моделями. При зменшенні доступних каналів кількість передач вторинних користувачів стає меншою. Кількість помилок між вторинними користувачами стає більшою, оскільки існуюча гібридна модель заснована на кількості вторинних користувачів i ймовірності доступу. Але введена концепція конкуруючого набору зменшує кількість помилок при занятті каналу і покращує доступ до обмеженої кількості каналів. На рис. 10 показано середній час очікування вторинних користувачів в чотирьох різних моделях при різній кількості зайнятих каналів. Середній час очікування вторинного користувача значно зростає в моделі перекриття тільки зі зменшенням доступних вільних каналів. У моделі поєднання кількість доступних каналів мало впливає на передачу даних вторинного користувача і суттєво не збільшує час очікування.

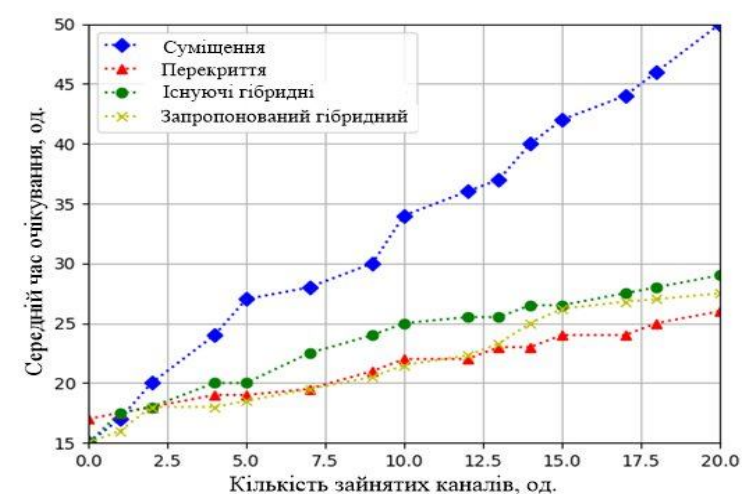

Рис. 10. Вплив моделі передачі даних на середній час очікування вторинного користувача при різній кількості зайнятих каналів

У моделі суміщення, інтенсивна передача інформації первинного користувача призводить до того, що деякі вторинні користувачі не можуть отримати доступ до каналів, що збільшує час очікування. Середній час очікування вторинних користувачів гібридної моделі з використанням нейронної мережі $є$ нижчим, ніж аналогічний параметр для існуючої гібридної моделі, але приймає вище значення, ніж модель суміщення тільки при великій кількості зайнятих каналів первинними користувачами. Як було описано вище, вторинні користувачі можуть передавати дані за рахунок використання моделі суміщення, за умови, коли первинний користувач отримує доступ до свого незайнятого каналу, a їх поточні конкуруючі набори залишаються активними. Вторинні користувачі, які конкурують більше ніж з одним каналом, можуть отримати доступ до каналу в інших конкуруючих наборах, за умови зайнятості поточного каналу. Тому середній час очікування вторинного користувача буде меншим при застосуванні гібридної моделі з використанням нейронної мережі. Але оскільки гібридна модель буде розподіляти пріоритет каналам, до яких можна отримати доступ в режимі перекриття, і поодиноких каналів ставатиме менше, середній час очікування вторинного користувача при застосуванні гібридної моделі буде нижчим, ніж в гібридній моделі з використанням нейронної мережі.

На рис. 11 показано середню «залишкову» енергію вторинного користувача у звичайній мережі когнітивного радіо, існуючу мережу когнітивного радіо 3 енергозбереженням [22] i запропоновану мережу когнітивного радіо зі збереженням енергії 3 використанням нейронної мережі в порівнянні 3 часом моделювання. Як показано на рисунку (11), технологія «Energy Harvesting» забезпечує необхідний рівень енергії для більш тривалого зв'язку. Крім того розроблена мережа когнітивного радіо з використанням «Energy Harvesting», за результатами моделювання, перевершує існуючу мережу когнітивного радіо з енергозбереженням. Як описано вище, вторинний користувач під керуванням нейронної мережі приймає рішення про відсутність вільних каналів для передачі даних або зайнятих каналів, для «збору» енергії, в залежності від стану буфера даних і кількості енергії. 


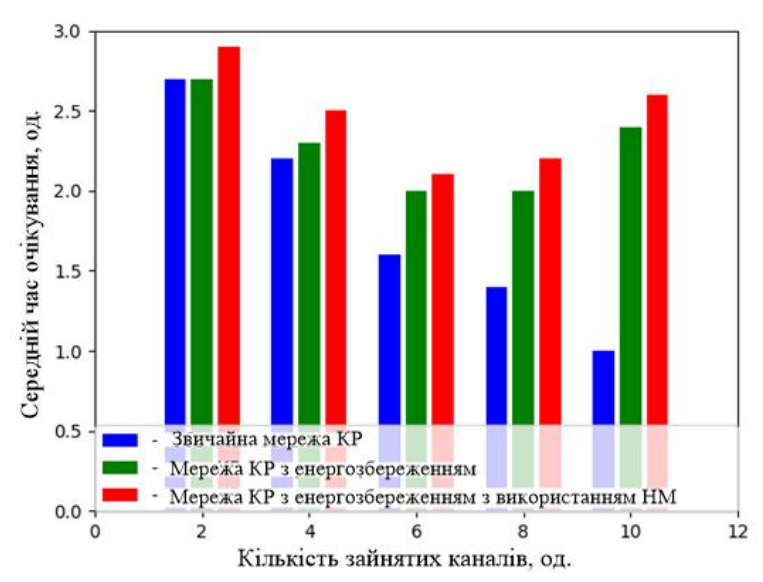

Рис. 11. Мережа когнітивного радіо зі збереженням енергії в різний час моделювання

Тобто вторинні користувачі можуть витрачати менше енергії для виявлення каналів. Також це сприяє тому, що вторинні користувачі мають більше часу для «збору» енергії, оскільки концепція конкуруючого набору може зменшити помилки, пов'язані 3 декількома конкуруючими вторинними користувачами для одного і того ж завантаженого каналу.

\section{Висновки}

У статті розглядалося вирішення задачі зменшення дефіциту спектра в телекомунікаційному середовищі. Розглядалася велика кількість вторинних користувачів в багатоканальній когнітивній радіомережі, в якій вторинні користувачі мають здатність «збору» енергії. У такій мережі ключовими проблемами $є$ конкуренція каналів між вторинними корис- тувачами та помилки при передачі вторинних користувачів в каналах 3 первинними користувачами.

Було запропоновано метод суміщеного використання спектра, для того щоб зменшити ймовірність помилок при виявленні вільних каналів і зменшити помилки при передачі вторинних користувачів. Для вирішення проблеми конкуренції каналів серед вторинних користувачів, було розроблено гібридну модель передачі для одного вторинного користувача. Кожен вторинний користувач може здійснювати передачу даних в незайнятому каналі або здійснювати «збір» енергії з каналу, в якому відбувається передача даних з урахуванням конкуруючого набору і стану ємності джерела безперебійного живлення. Також було розроблено методику визначення критерію вибору каналу для великої кількості вторинних користувачів на основі конкуруючого набору. Розроблена політика може забезпечити більш високу пропускну здатність у порівнянні з випадковою політикою. Головним недоліком випадкової політики є те, що такі помилки ніколи не будуть виявлені самі по собі і можуть тривати досить довго. Конкуруючий набір, який використовують вторинні користувачі в розробленому методі в значній мірі будуть усувати недоліки випадкової політики. Вторинний користувач може виявити помилку при передачі в фазі CS і припинить передачу на наступній фазі DT/EH, але розроблена модель дозволяє скоротити такі помилки до мінімуму. Запропонований метод суміщеного аналізу спектра і механізм визначення критерію вибору каналу перевершують відомі 3 точки зору ймовірності хибної помилки, середньої пропускної здатності, середнього часу очікування та ефективності «збору» енергії вторинного користувача.

\section{СПИСОК ЛІТЕРАТУРИ}

1. Shiang, H., van der Schaar. Distributed resource management in multi-hop cognitive radio networks for delay sensitive transmission. IEEE Transactions on Vehicular Technology, 58(2), 941-953,2012.

2. J. Jin, J. Gubbi, S. Marusic, and M. Palaniswami, "An information framework for creating a smart city through internet of things," IEEE Internet of Things Journal, vol. 1, no. 2, pp. 112-121, 2014.

3. C. Zhu, V. C. M. Leung, L. Shu, and E. C. H. Ngai, "Green internet of things for smart world," IEEE Access, vol. 3, pp. 2151-2162, 2015.

4. W. Li, C. Zhu, V. C. M. Leung, L. T. Yang, and Y. Ma, "Performance comparison of cognitive radio sensor networks for industrial IoT with different deployment patterns,” IEEE Systems Journal, 2015.

5. W. Li, V. Leung, C. Zhu, and Y. Ma, "Scheduling and routing methods for cognitive radio sensor networks in regular topology," Wireless Communications and Mobile Computing, vol. 16, no. 1, pp. 47-58, 2016.

6. Y. C. Liang, K. C. Chen, G. Y. Li, and P. Mahonen, "Cognitive radio networking and communications: an overview," IEEE Transactions on Vehicular Technology, vol. 60, no. 7, pp. 3386-3407, 2011.

7. E. Z. Tragos, S. Zeadally, A. G. Fragkiadakis, and V. A. Siris, "Spectrum assignment in cognitive radio networks: a comprehensive survey," IEEE Communications Surveys \& Tutorials, vol. 15, no. 3, pp. 1108-1135, 2013

8. X. Zhai, L. Zheng, and C. W. Tan, "Energy-infeasibility tradeoff in cognitive radio networks: price-driven spectrum access algorithms," IEEE Journal on Selected Areas in Communications, vol. 32, no. 3, pp. 528-538, 2014.

9. Y. Yilmaz, Z. Guo, and X. Wang, "Sequential joint spectrum sensing and channel estimation for dynamic spectrum access," IEEE Journal on Selected Areas in Communications, vol. 32, no. 11, pp. 2000-2012, 2014.

10. N. Khambekar, C. M. Spooner, and V. Chaudhary, "On improving serviceability with quantified dynamic spectrum access," in Proceedings of the IEEE International Symposium on Dynamic Spectrum Access Networks (DySPAN '14), pp. 553-564, McLean, Va, USA, April 2014.

11. T. M. C. Chu, H. Phan, and H. J. Zepernick, "Hybrid interweave-underlay spectrum access for cognitive cooperative radio networks," IEEE Transactions on Communications, vol. 62, no. 7, pp. 2183-2197, 2014.

12. V. Chakravarthy, X. Li, R. Zhou, Z. Wu, and M. Temple, "Novel overlay/underlay cognitive radio waveforms using sd-smse framework to enhance spectrum efficiency-part II: analysis in fading channels," IEEE Transactions on Communications, vol. 58, no. 6, pp. 1868-1876, 2010.

13. K. Karmokar, S. Senthuran, and A. Anpalagan, "Physical layer-optimal and cross-layer channel access policies for hybrid overlay-underlay cognitive radio networks," IET Communications, vol. 8, no. 15, pp. 2666-2675, 2014.

14. J. Zou, H. Xiong, D. Wang, and C. W. Chen, "Optimal power allocation for hybrid overlay/underlay spectrum sharing in multiband cognitive radio networks," IEEE Transactions on Vehicular Technology, vol. 62, no. 4, pp. 1827-1837, 2013.

15. H. Cho and G. Hwang, "An optimized random channel access policy in cognitive radio networks under packet collision requirement for primary users," IEEE Transactions on Wireless Communications, vol. 12, no. 12, pp. 6382-6391, 2013. 
16. S. Xie and Y. Wang, "Construction of tree network with limited delivery latency in homogeneous wireless sensor networks," Wireless Personal Communications, vol. 78, no. 1, pp. 231-246, 2014. View at Publisher

17. J. Shen, H. Tan, J. Wang, J. Wang, and S. Lee, "A novel routing protocol providing good transmission reliability in underwater sensor networks," Journal of Internet Technology, vol. 16, no. 1, pp. 171-178, 2015.

18. S. Sudevalayam and P. Kulkarni, "Energy harvesting sensor nodes: survey and implications," IEEE Communications Surveys \& Tutorials, vol. 13, no. 3, pp. 443-461, 2011.

19. Pratibha, K. H. Li, and K. C. Teh, "Energy-harvesting cognitive radio systems cooperating for spectrum sensing and utilization," in Proc. of the IEEE Global Communications Conference (GLOBECOM '15), San Diego, Calif, USA, December 2015.

20. S. Hu, Y. D. Yao, and Z. Yang, "Cognitive medium access control protocols for secondary users sharing a common channel with time division multiple access primary users," Wireless Communications and Mobile Computing, vol. 14, no. 2, pp. 284-296, 2014.

21. H. A. B. Salameh and M. F. El-Attar, "Cooperative OFDM-based virtual clustering scheme for distributed coordination in cognitive radio networks," IEEE Transactions on Vehicular Technology, vol. 64, no. 8, pp. 3624-3632, 2015.

22. S. Park, H. Kim, and D. Hong, "Cognitive radio networks with energy harvesting," IEEE Transactions on Wireless Communications, vol. 12, no. 3, pp. 1386-1397, 2013.

23. W. B. Chien, C. K. Yang, and Y. H. Huang, "Energy-saving cooperative spectrum sensing processor for cognitive radio system," IEEE Transactions on Circuits and Systems I: Regular Papers, vol. 58, no. 4, pp. 711-723, 2011.

24. P. J. Smith, P. A. Dmochowski, H. A. Suraweera, and M. Shafi, "The effects of limited channel knowledge on cognitive radio system capacity," IEEE Transactions on Vehicular Technology, vol. 62, no. 2, pp. 927-933, 2013.

25. S. P. Herath and N. Rajatheva, "Analysis of equal gain combining in energy detection for cognitive radio over Nakagami channels," in Proceedings of the IEEE Global Telecommunications Conference (GLOBECOM '08), pp. 1-5, New Orleans, La, USA, November 2008.

26. T. Yucek and H. Arslan, "A survey of spectrum sensing algorithms for cognitive radio applications," IEEE Communications Surveys \& Tutorials, vol. 11, no. 1, pp. 116-130, 2009.

27. M. G. Khoshkholgh, K. Navaie, and H. Yanikomeroglu, "Access strategies for spectrum sharing in fading environment: overlay, underlay, and mixed," IEEE Transactions on Mobile Computing, vol. 9, no. 12, pp. 1780-1793, 2010.

28. Y. Wang, P. Ren, F. Gao, and Z. Su, "A hybrid underlay/overlay transmission mode for cognitive radio networks with statistical quality-of-service provisioning," IEEE Transactions on Wireless Communications, vol. 13, no. 3, pp. 1482-1498, 2014.

Рецензент: д-р техн. наук, проф. С. І. Приходько, Український державний університет залізничного транспорту, Харків Received (Надійшла) 21.02.2018 Accepted for publication (Прийнята до друку) 18.04.2018

Разработка метода выбора каналов когнитивного радио при множественном доступе первичных и вторичных пользователей с использованием технологии «еnergy harvesting» под управлением нейронной сети

Я. С. Обиход, В. П. Лысечко, А. М. Прогонный, Г. Н. Качуровский, С. В. Сколота

Когнитивное радио (КР) является одной из основных частей телекоммуникационных систем связи (ТСС-IOE) в связи с тем, что были призваны решить вопрос дефицита спектра и внедрение интеллектуальных функций. Выбор канала с множественным доступом первичных пользователей (ПК) и вторичных пользователей (ВК) является одной из главных проблем стандарта. Из-за конкуренции каналов происходит взаимное влияние пакетов первичных и втринних пользователей. С целью уменьшения конкуренции каналов среди вторичных пользователей, был разработан метод выбора каналов когнитивного радио при множественном доступе первичных и вторичных пользователей с использованием технологии «Energy Harvesting» под управлением нейронной сети. На основе разработанного метода было реализовано гибридную модель передачи данных под управлением нейронной сети для каждого вторичного пользователя. Для этой модели характерны свойства, при которых вторичный пользователь может случайным не регламентированным образом работать в режимах совмещения с занятыми каналами с использованием технологии «Energy Harvesting» (EH) и перекрытия. Кроме того, для реализации разработанного метода был определен критерий выбора канала на основе конкуренции среди множественных запросов вторичных пользователей для передачи данных или технологии " Energy Harvesting ". На основе этого критерия создается конкурирующий набор последовательностей. Моделирование показывает, что предложенный метод совместного использования каналов и критерий выбора каналов превосходят другие методы с точки зрения ложной занятости (ошибки), средней пропускной способности, среднего времени ожидания и эффективности сбора энергии вторичного пользователя.

Ключевые слова: вторичный пользователь, сохранение энергии, когнитивное радио, коллизия, нейронная сеть, первичный пользователь, передача данных, радио волны, радиочастотный спектр.

\section{Development of cognitive radio codes selection method with multiple access of primary and secondary users} with the use of energy harvesting technology under the control of the neural network

Ya. Obikhod, V. Lysechko, O. Progonniy, H. Kachurovskiy, S. Skolota

Cognitive radio (CD) is one of the main parts of telecommunication communication systems (TCS-IOE) in connection with what was called to solve the problem of spectrum deficit and the introduction of intellectual functions. The choice of channel with multiple access of primary users (PCs) and secondary users (VCs) is one of the most important issues of the standard. Due to the competition of channels there is a mutual influence of packages of primary and secondary users. In order to reduce channel competition among secondary users, a method for choosing cognitive radio channels was developed at the multiple access of primary and secondary users using the technology "Energy Harvesting" under the control of the neural network. Based on the developed method, a hybrid model for data transmission under the control of the neural network for each secondary user was implemented. For this model there are properties in which a secondary user may randomly operate unregulatedly in combination with the occupied channels using the technology "Energy Harvesting" (EH) and the overlap. In addition, to implement the developed method, the criterion for choosing a channel based on competition among the multiple requests of secondary users for data transmission or the " Energy Harvesting" technology was determined. Based on this criterion, a competing set of sequences is created. The simulation shows that the proposed channel sharing method and the channel selection criterion outperform other methods in terms of false occupation (error), average throughput, average waiting time, and second-power energy efficiency.

Keywords: secondary user, energy conservation, cognitive radio, collision, neural network, primary user, data transmission, radio waves, radio frequency spectrum. 